\title{
11
}

\section{FACING THE CORONAVIRUS PANDEMIC IN THE CANADIAN FEDERATION}

\section{Reinforced dualism and muted cooperation? ${ }^{1}$}

\section{Johanne Poirier and Jessica Michelin}

\subsection{Introduction}

To begin with the obvious, size matters - and Canada is a large country. Second only in size to the Russian Federation, its area of $9,984,670 \mathrm{~km}^{2}$ is bordered by three oceans and the longest land frontier in the world to the south. With a population of 38 million, it is one of the world's least densely populated countries, although its largest city, Toronto, hosts 5 million people. There are 5.5 time zones in Canada. Although viruses, like pollution and people, do travel, what happens out west does not immediately affect what happens in the centre, the east, or the north. Geography matters and the coronavirus pandemic has underscored the huge regional diversity of the Canadian federation. Infection rates and deaths differed radically across the country, with the Atlantic provinces having fared better than New Zealand, and Québec having been similar to France, Belgium, or Spain. This reinforces the importance of looking beyond aggregate national statistics in comparative analysis.

Beyond geography lies another obvious element: federalism impacts on the fight against the microscopic enemy; conversely, fighting the virus impacts on the dynamics of federalism. In other words, when it comes to combating a pandemic, federalism - like size, population density, and regional diversity matters.

The Canadian federation is composed of ten provinces and three northern territories of widely different sizes. Canada, a country of immigration, is deeply multicultural and known for its 'complex diversity'. A federation founded by two groups of European descent, it is officially bilingual, and for a long-time was considered, at least in Québec, as 'bi-national'. With the - very belated recognition of the place of indigenous peoples in the complex polity, few today would challenge the idea that Canada is multinational. Throughout its history, 
Canadian federalism has had a differential impact on key actors (Gagnon and Poirier 2020). Unsurprisingly, the same is true in the context of the pandemic.

To use somewhat simplistic labels, Canadian federalism is officially 'dualist', pragmatically 'cooperative', multipolar, multicultural, multinational, symmetric in some ways, and asymmetric in others. The official division of powers is still outlined in a Constitution Act adopted by the Parliament of Westminster in the middle of the 19th century. Consequently, courts have played a major role in determining 'who can do what' in the Canadian federal system. Periods of decentralisation and centralisation have succeeded one another, with the last few decades heralding overlapping jurisdictions that challenge the dualist nature of the formal institutions. The Covid-19 pandemic underscored several of these paradoxes and grey zones.

This chapter examines the initial outbreak and first wave of infection (March-June 2020), the partial lull that occurred during the summer, and the beginning of the second wave, up to October 2020. In all three phases, the federal and provincial/territorial $(\mathrm{P} / \mathrm{T})$ governments acted largely in parallel, in keeping with the dualist nature of the federation; however, a fair degree of congruence in provincial action at the start gave way to differentiation in the later stages. Meanwhile, the federal order sought to keep the economy afloat by setting up financial aid packages and income replacement strategies. Although welcomed across the country, these costly initiatives were likely to generate the country's highest federal deficit in decades, and there were concerns that $\mathrm{P} / \mathrm{T}$ (and future generations) would eventually pay the price in the search for balanced budgets.

By the end of October 2020, about 235,000 cases and over 10,000 deaths had been reported. The vast majority of cases (77.2 per cent) and deaths ( 92.6 per cent) occurred in Ontario and Québec, which make up slightly more than 60 per cent of Canada's population. More remarkable - and rather hard to explain - was Québec's initial inordinate proportion both of cases and deaths. With only 23 per cent of the Canadian population, it accounted in the early stages for slightly less than half of all cases and slightly more than half of all deaths (Table 11.1).

By October 2020, Ontario and Québec faced a massive rise in infections. The Atlantic provinces were generally spared, and there were increases in the west. The situation was asymmetrical from the outset and remained so. The same is true of the country's responses to the pandemic. These facts and figures reflect the first six months of the pandemic and had to be taken with caution, as federal and provincial responses were in constant evolution.

Overall, the story of the federation's initial 'pandemic era' is one of parallel action by various orders of government, with cooperation taking place quietly and largely behind the scenes. There were hardly any jurisdictional turf battles. Provinces came out as 'real actors' alongside Ottawa. Unlike the situation in some federations that saw either centralisation or the creation of formal multilateral bodies under federal leadership, in Canada intergovernmental relations (IGR) did occur, particularly at the operational level, but were muted. 
TABLE 11.1 Canada: Covid-19 cases and deaths by province/territory (31 October 2020)

\begin{tabular}{lllll}
\hline & Cases & $\begin{array}{l}\text { Deaths } \\
\text { (total) }\end{array}$ & $\begin{array}{l}\text { Rate of cases } \\
\text { (per 100,00 } \\
\text { population) }\end{array}$ & $\begin{array}{l}\text { Rate deaths } \\
\text { (per 100,00 } \\
\text { population) }\end{array}$ \\
\hline Region & 14,733 & 263 & 290.52 & 5.19 \\
British Columbia & 28,245 & 323 & 646.14 & 7.39 \\
Alberta & 3,144 & 25 & 267.7 & 2.13 \\
Saskatchewan & 5,723 & 67 & 417.9 & 4.89 \\
Manitoba & 75,730 & 3,136 & 519.89 & 21.53 \\
Ontario & 106,016 & 6,246 & $1,249.46$ & 73.61 \\
Québec & 291 & 4 & 55.8 & 0.77 \\
Newfoundland and Labrador & 343 & 6 & 44.15 & 0.77 \\
New Brunswick & 1,109 & 65 & 114.17 & 6.69 \\
Nova Scotia & 64 & 0 & 40.78 & 0 \\
Prince Edward Island & 23 & 1 & 56.3 & 2.45 \\
Yukon & 10 & 0 & 22.31 & 0 \\
Northwest Territories & 0 & 0 & 0 & 0 \\
Nunavut & 235,431 & 10,136 & 617.19 & 26.9 \\
Total & & & & \\
\hline
\end{tabular}

Source: Public Health Agency of Canada (2020a)

\subsection{The federal constitutional and legislative framework}

Despite the 'pragmatically' cooperative nature of Canadian federalism on a dayto-day basis, the fundamental structure of the federation remains dualist (Poirier 2020). Each order of government has its own legislative and executive - and to a certain extent, judicial - branch. The delegation of administrative and regulatory functions is possible between orders of government, but generally $\mathrm{P} / \mathrm{T}$ are not seen as implementers of federal law or programmes. The management of the Covid-19 crisis was no exception.

Innumerable policy areas were implicated in the fight against the pandemic. They ranged from public health and health-care delivery, elderly care and schools, and medical research to policing, prisons, fiscal and financial arrangements, relations with indigenous nations, emergency measures, border closures, and more. The following discussion focuses though on health and disaster management.

The relevant constitutional provisions are vague and have been interpreted broadly. Particularly in the recent past, the Supreme Court of Canada has invoked 'cooperative federalism', not in order to impose cooperation (or any form of loyalty) on members of the federation, but to facilitate jurisdictional overlap (Gaudreault-DesBiens and Poirier 2017). This allows all orders of government to intervene in matters of health and disaster management, increasing the possibility of public action. It also leaves the responsibility for sorting out 'who should do what' to the political branches, which coordinate - or not - the various interventions. 
Coordination takes place through a plethora of means that have no constitutional - and hardly any legislative - grounding. There is little official input by constitutive units into federal law- or decision-making, particularly since the Canadian Senate is inadequate as a body of provincial or regional representation - Canada's model is the archetype of 'inter-state' federalism (Broschek 2020). Consequently, in the context of Covid-19, a significant degree of informal consultation regularly occurred through pre-existing as well as ad hoc intergovernmental channels.

\subsubsection{Public health, health-care delivery, and elderly care facilities}

As the Supreme Court noted, health is an amorphous topic which can be addressed by valid federal or provincial legislation, depending [on] the circumstances' (Carter v. Canada (AG) 2015 SCC 5: paragraph 53). While in theory each order's action finds its constitutional grounding in an exclusive power, there is, in practice, a substantial degree of de facto concurrency (Steytler 2017: 7). This generates both interdependence between orders of government and confusion about who can do what.

\subsubsection{Federal constitutional authority and legislation}

Ottawa's explicit powers over health are limited to 'quarantine', 'marine hospitals', and 'patents', including those for pharmaceuticals (Constitution Act of 1867 [CA, 1867], section 91(11) and 91(22)). Of increasing relevance is reliance on the federal 'criminal law' power to intervene in matters of public health (CA, 1867, section 91(27); Klein 2017). Explicit federal authority over certain classes of people, such as indigenous peoples and immigrants, extends to their health care and is exercised in conjunction with provinces. Ottawa has an important department of health and an arm's-length public health agency.

Numerous federal statutes address health matters. The Quarantine Act of 2002, for example, enables the federal administration to prohibit entry into Canada or subject it to strict conditions. It foresees some intergovernmental collaboration, including mandatory notification to provinces of suspected infected persons. It also authorises delegating the administration and enforcement of quarantine measures to provinces.

\subsubsection{Provincial constitutional authority and legislation}

Provinces bear the brunt of the burden of health-care delivery. Provincial power over health is rooted in one explicit section regarding hospitals and the very broad powers over 'property and civil rights' and 'matters of a merely local or private nature' (CA, 1867, section 92(7), 92(13) and 92(16)). In practice, provinces are responsible for hospitals, and structuring public health care, among other 
things. They are also responsible for long-term care for the elderly - the population segment in which, in the first wave, most of the cases and deaths occurred.

Each province and territory has its own legislative and regulatory health scheme. Moreover, certain indigenous communities exercise a degree of selfgovernment, including in regard to health matters. The overall public character of the health-care system depends largely on targeted federal financial transfers to provinces, with a loose conditionality set out in the Canada Health Act of 1985. These transfers have decreased significantly over the last several decades, a trend which provincial leaders have decried for years and which became acute during the Covid-19 pandemic.

\subsubsection{Disaster and emergency management}

As with health care, jurisdiction over disaster and emergency prevention and management is not explicitly provided for in the Constitution. In practice, it is a shared responsibility, with each order acting pursuant to some of its - officially exclusive powers. In the Covid-19 context, it is mostly provincial emergency powers that have been mobilised.

\subsubsection{Federal constitutional authority and legislation}

Courts have grounded the federal emergency power in the 'peace, order and good government' clause (CA, 1867, section 91, preamble). The effect of invoking the federal emergency power is a temporary federal take-over of provincial jurisdiction. The potential political fallout of such drastic action is a key limiting factor in the federal government's decision to invoke this power (Deschenes 1992). A number of federal statutes provide legislative grounding for federal action in dealing with health emergencies. In the context of Covid-19, the Emergencies Act of 1988 and Emergency Management Act of 2007 stand out.

The former identifies four types of emergencies: public welfare, public order, international, and war. The classification affects permissible actions and the duration of the emergency declaration. Noteworthy, the Act subjects these measures to the Canadian Charter of Human Rights and Freedoms and provides for detailed parliamentary oversight mechanisms. It also explicitly recognises provincial jurisdiction over emergencies, imposes consultations, and invites concerted intergovernmental action. Parliament has thus strongly limited the conditions under which a 'federal take-over' could occur.

For its part, the companion Emergency Management Act addresses emergency preparedness. It outlines the responsibilities of the federal minister of public safety. These include supporting - not overseeing - provincial or local emergency initiatives, establishing intergovernmental arrangements for consulting cabinet with respect to declarations of emergencies, and providing assistance - including financial to provinces on request. As with the Emergencies Act, a federal institution may not respond to a provincial emergency unless the province requests assistance. 
Read in this way, both Acts seem like models of federalism of the type based on respect for provincial autonomy. The Emergencies Act was not activated in response to Covid-19, but the Emergency Management Act gave rise to some degree of intergovernmental preparation prior to the outbreak, steps which were initiated in March 2020.

\subsubsection{Provincial constitutional authority and legislation}

In parallel with the federal order's powers in the context of emergencies, provinces also have jurisdiction over disaster management and emergencies in areas that fall within their own sphere of competence (Deschenes 1992). This is not pursuant to any explicit constitutional provision but rather to provinces' authority over 'local matters' and the administration of justice (which includes the police) (CA, 1867, sections 92(13)-(14)). In some P/Ts, governmental departments have emergency response plans similar to federal ones.

The 'real' federal emergency power needs to be activated through a formal declaration by the governor-general, which did not occur. In a way, provincial emergency powers are the baselines, with the federal one understood as the exception. Later, in Section 11.4.2, we address the question of why a federal emergency was not declared.

\subsection{Preparedness for a national disaster: The institutional framework}

A number of intergovernmental committees and agreements were already in place at the beginning of the pandemic. Many of these structures were developed in the wake of Canada's poor response to the outbreak in 2003 of SARS (severe acute respiratory syndrome), a response characterised by a lack of coordination between Ontario's provincial authorities and the federal order (Fierlbeck and Hardcastle 2020).

The Public Health Agency of Canada (PHAC) is a federal institution, not a multilateral one, yet its mandate includes promoting intergovernmental collaboration on public health policy and planning. Meanwhile, the Pan-Canadian Public Health Network is the primary intergovernmental body dealing with public health. It is governed by a council composed of federal and P/T government officials and is accountable to another group of civil servants, the federal and $\mathrm{P} / \mathrm{T}$ deputy ministers of health. The network has developed a number of intergovernmental agreements establishing frameworks for information-sharing and assistance with health resources during health emergencies.

The key intergovernmental agreement is the Federal/Provincial/Territorial Response Plan for Biological Events (Pan-Canadian Public Health Network 2018a). It sets out a governance structure and articulates a complex response-pathway from notification of potential threats to post-incident review. It also outlines possible responsibilities for each order of government, including areas of overlap. 
When a coordinated response is deemed necessary, a special advisory committee is established to advise the deputy ministers of health. The Plan also anticipates a plethora of working groups to address technical issues, logistics, and communications (McNeill and Topping 2018).

In addition to this general response plan, the network developed a specific pandemic flu guidance framework, articulated in the document, Canadian Pandemic Influenza Preparedness: Planning Guidance for the Health Sector (Pan-Canadian Public Health Network 2018b). Intended to guide the development of a consistent and coordinated $\mathrm{F} / \mathrm{P} / \mathrm{T}$ pandemic response, it - again - seeks to clarify responsibilities for each order of government regarding laboratory services, public health measures, vaccines, and so on.

Four other intergovernmental agreements are worth noting. The Multilateral Information Sharing Agreement (Pan-Canadian Public Health Network 2014) sets out the terms for sharing information relevant for routine surveillance, case management, and responses to infectious diseases. The Memorandum of Understanding on the Provision of Mutual Aid in Relation to Health Resources during an Emergency Affecting the Health of the Public (Pan-Canadian Public Health Network 2009) establishes a framework for interjurisdictional sharing of health resources during public health crises. This led to the development of the Operational Framework for Mutual Aid Requests (OFMAR), a non-binding mechanism to operationalise the general framework and allow P/Ts to identify and share healthcare professionals and assets across jurisdictional boundaries during public health events (Framework for Mutual Aid Requests (OFMAR) n.d.). Even more specifically, in August 2020, PHAC released the collaboratively developed F/P/T Public Health Response Plan for Ongoing Management of Covid-19 (Public Health Agency of Canada 2020b). It uses epidemiological modelling to predict different scenarios and anticipate various responses until vaccines or treatments are in place.

In short, while the Response Plan for Biological Events sets out the governance structure, at least four intergovernmental agreements anticipate operational responses to a pandemic; the Covid-19 Plan detailing respective responsibilities for the current crisis. None of these agreements have statutory force, however. They are intergovernmental executive instruments, often written in rather hortatory language, and probably even lacking in contractual force between the executive branches party to it (Poirier 2004).

\subsection{Rolling out measures to contain the pandemic}

A federal election in the autumn of 2019 saw the incumbent Liberal Party retain power, though as a minority government. Partisan politics are never hugely relevant in IGR in Canada (Adam et al. 2015). They barely played a role in the initial response to Covid-19, either in the intergovernmental context or within orders of government. In fact, political leaders who did not get along particularly well, or had distinct political agendas, showed remarkable respect for one another during the first six months of the pandemic. 
While there was some later fracturing of this united front, criticism was directed less at the health crisis management and more at deficit-creating spending (federally) and at needs for greater funding (from provinces). Regardless of political affiliation, Canadians expressed high levels of satisfaction with the initial government responses (Harell 2020). With time, greater opposition was voiced through party politics, but it remained moderate and cordial (Noël 2020).

\subsubsection{Taking the initiative}

The measures set out in the Response Plan for Biological Events were activated by the federal PHAC in early January 2020 and a special advisory committee was established. By early March, the virus was spreading exponentially in certain regions. This asymmetrical impact saw some provinces mobilising more quickly than others. That being said, in contrast to the more disjointed reopening schemes that were implemented as the pandemic progressed, these first initiatives took place in relatively close concert with each other.

On 13 March 2020, Québec became the first of Canada's governments to declare a public health emergency, in the process shutting down schools, universities, and day-care centres and forbidding indoor gatherings of more than 250 people. Subsequent provincial orders prohibited all indoor and outdoor gatherings and proscribed visits to hospitals and seniors' residences. Interregional travel was also banned and enforced by road blockades. An executive order gave Québec's Minister of Health and Social Services enhanced powers, including the authority to contract without public tender. Legal prescription periods were suspended, as courts were closed for all but urgent matters. In short, the declaration of a public health emergency thrust Québec into a full-on pandemic response.

Four other provinces (Prince Edward Island, Ontario, British Columbia, and Alberta) all declared public health emergencies prior to significant federal response, which occurred on 18 March. Saskatchewan, Newfoundland, Labrador, and the three territories declared an emergency on the day the federal government closed the border with the United States, while New Brunswick, Manitoba, and Nova Scotia declared public health emergencies in the days thereafter (Breton and Tabbara 2020).

A federal response group was convened at the end of January 2020 to monitor the virus. Initial actions had an international focus, first with travel warnings and then repatriation of Canadians stranded abroad. In March, a special cabinet committee was established to ensure a whole-of-government response. From mid-March, all foreign nationals were banned from entering Canada (with limited exceptions) and anyone entering the country, including Canadians, had to quarantine. While public authorities take note of World Health Organization decisions, their actions do not seem to have been directly influenced by any supranational considerations. 


\subsubsection{Federal action}

Federal actions can be broadly classified into five categories. The first were measures taken pursuant to various areas of federal jurisdiction. Regulations and orders were issued addressing quarantine, air, rail and marine travel, drug safety, financial administration, federal prisons, indigenous services, and immigration and justice matters. In tandem with the provinces, Ottawa scaled up its procurement of medical supplies and personal protective equipment (PPE) and negotiated with pharmaceutical companies to procure an eventual vaccine. ${ }^{2}$

Secondly, responding to provincial requests, the Canadian armed forces sent personnel to 54 long-term care homes (47 in Québec and 7 in Ontario). In the first wave, 80 per cent of deaths occurred in these institutions, which were woefully ill-prepared compared to hospitals. Soldiers were also deployed to remote areas, notably to support indigenous communities (National Defence 2020).

A third set of initiatives provided direct financial support to citizens, organisations, and interest groups. Two 'omnibus' bills (Covid-19 Emergency Response Act Nos. 1 and 2, 2020) dealt with tax deferrals, insurance, the housing mortgage industry, student loans, farm credit, and the like. A wage subsidy programme for businesses, along with temporary income benefits for workers and students unable to work, were rapidly introduced. Funding was also mobilised to support scientific industry research, including vaccine development.

Fourth, Ottawa supported provincial initiatives, much in the way it does in non-pandemic times. Pursuant to the multilateral Safe Restart Agreement, concluded in September 2020, Ottawa would transfer CAD 19 billion to provinces and territories for a range of measures, with $\mathrm{P} / \mathrm{Ts}$ specifying their respective needs (Intergovernmental Affairs 2020). These included testing, tracing, health care, long-term care support, PPE procurement, child care, and support for municipalities. Additional funding targeted, inter alia, homelessness, gender-based violence, indigenous communities, and schools.

The fifth category of federal action includes the issuance - often in an intergovernmental setting - of guidance frameworks in a flurry of domains, often within provincial jurisdiction, such as virtual health-care delivery, schools, longterm care, and funeral homes. Ottawa also developed a smartphone tracing app into which provinces could co-opt.

Perhaps strikingly from a comparative perspective is what the federal order did not do: declare a full-on pan-Canadian state of emergency. While there is no doubt that the Emergencies Act could have been invoked, it was not, for at least five reasons. To begin with, it was not truly necessary. The federal government could close borders, impose quarantine, and assist provinces - including deploying the army - under existing legislation. Secondly, every $\mathrm{P} / \mathrm{T}$ rapidly declared 'health emergencies'. Given that the pandemic affected regions differently - as noted, geography matters - a wholesale, one-size-fits-all solution was not warranted, particularly in that the $\mathrm{P} / \mathrm{T}$ generally all adopted restrictive measures, at any rate in the early stages. 
Thirdly, the Emergencies Act requires provincial buy-in, mostly in the form of consultation and, where it is the case that an emergency is localised, actual provincial consent. Ottawa chose to heed the provinces' express reluctance to see the Act invoked. Fourth, the Emergencies Act places the executive branch under strict parliamentary scrutiny. Parliamentary sittings were reduced as of mid-March and used mostly to adopt specific legislation (introducing financial aid packages, for instance). The executive was even authorised to circumvent the need for appropriations bills (An Act to amend the Financial Administration Act (special warrant), 2020; MacDonnell 2020). Parliament was in fact suspended between mid-August and 23 September 2020. Meanwhile, the Senate, including its committees, resumed sitting in any regular manner only in October. Overall, Parliament was less mobilised than it would have been under the Emergencies Act. Hence, paradoxically, not invoking it probably increased the federal executive's room for manoeuvre (Leuprecht 2020).

Finally, for reasons unrelated to the pandemic, there was political reluctance in Ottawa, at least under Liberal leadership, to invoke federal emergency powers. The last time these were put into action was in the 1970 October Crisis when a foreign diplomat was kidnapped and a provincial minister killed, in the context of claims for Québec's independence. At the request of the Québec government, Ottawa had sent the army to Montreal, civil liberties were suspended, and nearly 500 people imprisoned, most of them without being charged. The federal prime minister at the time, Pierre Elliott Trudeau, was the father of the current Prime Minister, Justin Trudeau. It is likely that the latter sought to avoid rekindling that saga 50 years later, even if in very different circumstances.

In brief, emergency powers were in place as of March 2020, but only within provincial and territorial legal orders. Federal action was grounded instead in other - less politically sensitive and constraining - legislation. As the third wave of infection began to spread, it remains to be seen whether the federal government might change its strategy in favour of a more centrally driven response. But this, in our view, is unlikely.

\subsubsection{Provincial and territorial action}

It will be apparent by now that there were (at least) 13 different pandemic regimes in Canada, each corresponding to the circumstances of a P/T (and in some cases, those of indigenous communities). Nonetheless, there was initially a degree of convergence. The following is a partial survey of the measures taken.

Between March and September 2020, all 10 provinces declared a state of emergency. At different points, they all closed schools, restaurants (except for take-out), and bars, radically restricted visits to long-term care centres, prohibited residential evictions, and limited gatherings indoors and outdoors. Moreover, most constitutive units closed day-care centres, sport facilities, and cultural centres (Breton and Tabbara 2020). All P/T legislative assembly meetings were temporarily suspended (Sahota 2020). 
Extraordinary measures affecting labour and employment law were taken. Just within Québec, executive orders suspended the terms of some collective agreements, allowing forced overtime for health-care staff, preventing them from taking vacation, and permitting compulsory reassignment. The latter measure led to health-adjacent personnel such as speech therapists being sent to fill staffing shortages in long-term care homes. While many drastic measures were lifted during summer, some were re-implemented in autumn.

In addition to federal initiatives, some provinces introduced financial support measures, such as grants and loan-forgiveness for small businesses, investment programmes for hard-hit industries (e.g., restaurants and the arts), and bonuses for essential workers (Lee and Hamidian 2020). However, certain provinces were criticised for clawing back federal assistance payments (Béland et al. 2020a).

Given the significantly divergent impact of the pandemic in the first wave, there was noticeably greater variation in reopening protocols than observed in the initial shutdown. In some provinces, students returned to classes in the spring, while others waited until autumn. Ontario offered a choice between virtual classrooms or in-class teaching, while Québec favoured in-person schooling until it opted for limited 'alternate days' for some students when the second wave expanded. There was a patchwork of mandatory mask mandates, with some provinces leading the charge and others leaving the decision to local authorities. At least four provinces (Manitoba, New Brunswick, Québec, and Ontario) created a colour-coded system to introduce measures of variable intensity in different intra-provincial regions. The strict approach taken by the territories may be explained in part by their particular geographic situation as remote Northern communities, where accessing health resources is a challenge. This is compounded by demographics, as territories have significant indigenous communities, often marginalised in the Canadian health-care system.

Particularly fascinating was the asymmetrical closure of interprovincial borders. The Atlantic provinces created an 'Atlantic travel bubble' whereby anyone entering from the rest of the country had to self-isolate for 14 days upon arrival, with some exceptions made for the eastern parts of Québec. This paid dividends - the region was spared the high death rates and resurgent infection rates observed elsewhere. Nunavut and the Northwest Territories created a two-unit travel bubble. Manitoba required self-isolation for anyone entering the province from the east, but not the north or west (where infection rates were lower). Saskatchewan, Québec, and Manitoba limited intra-provincial travel to protect certain regions or indigenous communities regarded as vulnerable.

Canadians enjoy a constitutional right to move across the country, subject to limitations deemed justifiable in a 'free and democratic society' (CA, 1982, sections 1, 6(2)). While Ottawa could limit or prohibit inter- and intra-provincial travel under the Emergencies Act, whether provinces have constitutional jurisdiction to take similar actions is unclear. A court in Newfoundland ruled that the province's severe travel restrictions (before the creation of the Atlantic bubble) were valid exercises of provincial power and constituted reasonable limitations 
on mobility rights, given the nature of the pandemic (Taylor $v$. Newfoundland and Labrador, 2020 NLSC 125). This decision was being appealed, and other challenges targeting travel restrictions were also making their way through the courts.

By and large, few courts have issued decisions assessing the legality of government decisions in response to Covid-19 in general. In addition to challenges to interprovincial travel bans, legal action has targeted occupational safety regulations regarding the use (or not) of PPE, confinement and social distancing, mandatory masks, and return to school protocols. In any event, it is doubtful that judicial review can compensate for shortcomings in political accountability, given the courts' deferential attitudes to valid delegations of authority (Daly 2020a).

Parliamentary scrutiny of executive action also varied across provinces. As with the federal parliament, several provincial legislatures adapted their schedules, often with virtual options (Sahota 2020). Much of the regulatory activity related to the Covid-19 response occurred through subordinate legislation, in the form of ministerial orders, which are not subject to legislative debate (Daly 2020b).

\subsubsection{Local government actions}

Under Canadian law, municipalities do not constitute a third order of government. Local authorities only enjoy powers delegated through provincial legislation. That said, while their autonomy is formally limited, they have a wide range of responsibilities, all of which the health crisis put to the test (Flynn 2020). For example, many cities reimagined urban spaces to facilitate social distancing and distributed free masks to citizens even in the absence of province-wide mask mandates. The limitations of municipal authority were also evident. For instance, Toronto's health director lacked power to implement enhanced public health measures at the beginning of the second wave and issued a call for Ontario's top health officer to take action.

Municipalities raised concerns about the strain the crisis was putting on their budgets. The misalignment of revenue and expenditure responsibilities was the greatest for municipalities, with the Federation of Canadian Municipalities calling for CAD 10 billion in emergency federal funding (Béland et al. 2020c). This pan-Canadian organisation created a Covid-19 website highlighting available municipal resources and local innovation. That apart, there did not seem to be any ground-breaking sharing of best practices to maximise the 'laboratory' potential of decentralisation, albeit information-sharing certainly took place, nor was there systematic coordination between regional and municipal authorities.

\subsubsection{Intergovernmental relations}

There is a general consensus that federal and $\mathrm{P} / \mathrm{T}$ intergovernmental communication during the first wave of the pandemic response was fairly effective (Schertzer and Paquet 2020a). Governments avoided undermining each other's public health directives, in stark contrast with the situation south of the border. 
Federal and $\mathrm{P} / \mathrm{T}$ leaders publicly committed to ongoing collaboration when restarting the economy and de-escalating public health measures.

The fact that Ottawa did not invoke federal emergency powers probably set a positive tone of respect between orders of government. Nonetheless, certain measures that were announced at the opening of Parliament in September 2020 potentially altered that sentiment. For instance, Ottawa suggested that it might impose 'national standards' on long-term care homes. As it does not have constitutional authority in this area, it could act only through its spending power. This announcement annoyed some provinces, which reaffirmed their jurisdictions and called for increased - and unconditional - federal funding.

By contrast to Belgium's National Security Council, or Australia's 'National Cabinet', there was very little structured or visible interaction between governments. Federal press conferences were held in parallel with those of the provinces. The public was simply told that regular phones calls were being made among the top leadership. Informal discussions with senior civil servants reveal that a lot of intergovernmental communication and consultation took place in a wide range of contexts. These were grounded in existing emergency preparation plans but also emerged spontaneously as the need arose.

The pandemic generated creative forms of horizontal cooperation, particularly between provinces with regional and economic ties. The eastern provinces have a history of regional cooperation, including in the health sector, which may explain the fact that they managed to forge the 'Atlantic bubble'. Québec and Ontario premiers and several members of their cabinets held joint meetings. That being said, provinces generally acted with a great deal of autonomy, with calls made for greater interprovincial action and pooling of best practices.

The degree to which pre-existing intergovernmental arrangements were effected in practice is also unclear. The detailed three-layered coordination frameworks set out in the Response Plan for Biological Events, the Pandemic Influenza Preparedness Plan, and the specific Covid-19 plan seem to have been mobilised, although the extent to which they were followed, or were effective, remains difficult to ascertain. Similarly, while the federal government made billions of dollars in funding available to the provinces, little information was publicly available about the details of the funding agreements. Formal sources of horizontal cooperative arrangements, such as the Atlantic bubble, are also difficult to access. What one saw were the results, but not the processes or legal mechanisms on which they were built.

In short, IGR remain executive-led. They are apparently widespread, relatively effective, and quietly innovative - and as opaque as ever.

\subsubsection{Intergovernmental fiscal relations}

Canadian fiscal federalism faced major criticism prior to the pandemic - the economic challenges created by Covid-19 only exacerbated some of these tensions. While provinces enjoy substantial taxing powers, the federal order has 
much greater fiscal capacity; meanwhile, the cost for provinces of meeting their responsibilities continues to rise. This imbalance was reinforced by the fact that key areas impacted on by the pandemic - such as health care, long-term care, education, housing, and most social assistance programmes - are provincial responsibilities. Although Ottawa announced major financial transfers to $\mathrm{P} / \mathrm{Ts}$ in response to the pandemic, securing the funding was likely to prove challenging, given the politics of negotiating bilateral transfer agreements. Québec in particular has been a vocal opponent of conditional federal funding.

Scholars have suggested that Covid-19 might provide the momentum for significant structural changes in Canadian fiscal federalism or certain federal redistribution programmes such as (un)employment insurance (Béland et al. 2020b; Noël 2020). Political actors were certainly trying to seize the opportunity, with Québec and Ontario advocating for increased health-related transfers. Alberta, which has been a net contributor to fiscal equalisation for decades but has been facing a major economic crisis since the prices of fossil fuel crashed, also pushed for reforms to fiscal federalism, even calling for a referendum to launch a constitutional reform of fiscal equalisation across the federation.

\subsection{Findings and policy implications}

\subsubsection{Effectiveness of the federal system}

Mixed conclusions are drawn from the Canadian response to the first wave of Covid-19. At one end of the spectrum, some maintain that Covid-19 underscores the strength of a decentralised system in that it allows for effective asymmetrical responses (Mathieu and Guénette 2020). Diversity in epidemiological and geographical realities calls for localised solutions. High infection rates in some provinces did not lead to widespread outbreaks in neighbouring ones. This might be explained in part by the high degree of convergence in initial provincial responses and the unprecedented closure of domestic borders. Indeed, some provinces were modelling solutions based on other provinces' experiences. Migone notes that compared to the SARS outbreak, there was greater cooperation, a trend she attributes to Canada's tradition of executive federalism, including the interjurisdictional bodies and agreements specifically designed to palliate policy fragmentation and jurisdictional turf wars (Migone 2020). We see subsidiarity as well as 'cooperative' and 'laboratory federalism' at play.

At the other end of the spectrum, critics argue that Canada's Covid-19 response was bungled due to a weak federal presence. Notably, they criticise the Multilateral Information Sharing Agreement, which allows provinces to limit the publication of data otherwise needed to craft effective responses (Attaran and Houston 2020). The extent to which Ottawa could impose health-data-sharing on provinces is, however, uncertain from a constitutional perspective. Others also called for greater federal action, not through the Emergencies Act - which only justifies federal temporary intervention - but through the initiation of 
pan-Canadian policy responses to address social problems arising from (or exacerbated by) the pandemic (Lee and Hamidian 2020). This would likely generate jurisdictional battles.

Somewhere in the middle, others reject greater centralisation but also deplore ad hoc mechanisms activated only during a crisis and the lack of sustained, coordinated actions. This contributes to thin intergovernmental trust (Schertzer and Paquet 2020b). In response to this intergovernmental weakness, Da Silva and Saint-Hilaire call for a new multilateral intergovernmental agreement to clarify roles and responsibilities and increase vertical and horizontal coordination (Da Silva and Saint-Hilaire 2020). They suggest that an intergovernmental agreement would ease provincial concerns about federal intrusion, as intervention conditions would be outlined and agreed upon. Unfortunately, they do not identify precise failings of the current intergovernmental bodies and agreements - a failure which only serves to underline the opacity of IGR alluded to previously.

\subsubsection{Impact on the federation's multinational character}

It is generally admitted that systemic issues make indigenous populations more vulnerable to Covid-19, with such issues including overcrowded housing, homelessness, high incarceration rates, inadequate health services, food insecurity, lack of clean water, and the remoteness of northern, fly-in communities (Carling and Mankani 2020). In addition to the differential impacts of urban/rural and on-reserve/off-reserve divides, the tug-of-war between Ottawa and provinces regarding services to indigenous peoples is bound to have an impact in crisis situations (Poirier and Hedaraly 2020). Some indigenous communities adopted self-isolation measures, such as putting up road blocks to prevent visitors from entry. For outside observers, what is striking is that indigenous peoples seemed to be largely absent from public media as interlocutors or decision-makers; the narrative instead was mainly about 'protecting' these communities. This seems to contrast with the place which reconciliation and the call for indigenous selfgovernment occupied in public discourse just prior to the pandemic.

Unsurprisingly, a new chapter in the Québec-Canada story was also unfolding. At least since the 1960s, Québec has considered itself a distinct nation within Canada. Yet appeals by the premier to the special solidarity that Québécois are supposed to share with each other did not appear to resonate strongly with the population. Health care and old-age housing - under provincial jurisdiction proved to be dramatically inadequate. Initially at least, infection and death rates were initially - inexplicably - higher in Québec than in the rest of the country. Sociologists will have much to reflect upon in considering the impact of the pandemic on Québec's sense of 'distinctiveness' and how this played out in its commitment to, or rejection of, the federal system.

The Québec government's decision to request military assistance in staffing long-term care homes was undoubtedly difficult for what is not an officially independentist but nationalist government. When Québec requested that the 
military remain until autumn, the federal government refused. Québec replied that its tax contributions help fund the military (National Assembly 2020). As a compromise, the Canadian Red Cross stepped in to fill personnel shortages ... with federal funding!

French-speaking minorities in other provinces saw their linguistic rights abridged during the pandemic. Since the outbreak, respect for linguistic obligations in certain public institutions and governments gradually diminished (Chouinard and Normand 2020). For example, Ottawa exempted certain products from bilingual labelling. In New Brunswick, the only officially bilingual province, the premier refused simultaneous interpretation services during briefings and even ignored questions from French-speaking journalists. In contrast, Québec authorities conduct a (limited) part of all briefings in English, and key communications were available in both languages on government websites (as it is for the federal order).

The extent to which public messaging reached immigrant communities was also of concern, particularly given that some of these communities were hard-hit by the virus. Several provinces, notably British Columbia, disseminated information in a number of languages other than French and English.

\subsubsection{Looking to the future: Quo vadis, the federal spirit?}

The impact of federalism on pandemic management is a trade-off (Migone 2020). The Canadian model's strength is its ability to tailor responses to different needs; the cost is a lesser degree of coordination, even when it would be beneficial. This, of course, is a textbook instance of the advantages and disadvantages of federalism.

A main thread in the story is that both provinces and the centre remained strong actors during the pandemic in 2020. Despite the absence of constitutionalised and structural inputs into federal law-making, several key federal acts do call for consultation and coordination with provinces. Ottawa's decision not to invoke the Emergencies Act - particularly in the face of provincial resistance suggests that it did not seek to play a dominant role. Federal action, especially of such a pronounced kind, would have required serious provincial buy-in.

Also noteworthy during the Covid-19 crisis: orders of government did not raise jurisdictional obstacles to each other. When Québec sent officials to the Montreal airport prior to federal action on Ottawa's part, the latter did not flinch, nor did it object to provinces closing internal borders. Despite the absence of any recognised principle of subsidiarity in Canadian constitutional law, the federal order was probably only too relieved to leave these difficult decisions to provinces. In turn, the Québec government called upon the army and allowed Ottawa to set up new emergency - income replacement programmes. In a federation where governments use courts fairly regularly to clarify federal issues, it is striking that basically no challenges to actions taken by any order of government seem to have been considered. Whether this constitutional truce will last was, of course, an open question. 
In the landscape of Canadian federalism, the real test moving forward will be managing the aftermath of Covid-19. Numerous economic response measures have generated the highest federal deficit since the 1960s. This is bound to have a major impact on equalisation and transfer payments. The resultant social problems are likely to fall in the provinces' backyards, as they did in the 1990s during a period of federal fiscal austerity, apart from the issues of who will pay for the required measures, and how, the situation risks increasing fiscal inequality between provinces (Noël 2020). These concerns are exacerbated by serious budgetary problems in British Columbia and Alberta, which are historically net contributors to equalisation.

Interprovincial solidarity is thus both reinforced and tested. Regional blocs have emerged to improve public health measures but so too for maximising bargaining power and political pressure on the federal government. Meanwhile, solidarity has also been strained for non-pandemic reasons, such as environmental policy and fiscal redistribution. Vertical and horizontal friction will be heightened in the course of events as orders of government attempt to recover from the economic impact of Covid-19. In their reading of Canada's experience in 2020, Schertzer and Paquet see complex intergovernmental problems being met initially in a collaborative manner, only to give way to subsequent conflict (Schertzer and Paquet 2020b). This suggests that we should anticipate that rising intergovernmental tensions will partly displace the current cooperation and interjurisdictional respect as the pandemic and its aftermath unfold.

\section{Notes}

1 We thank Atagün Kejanlioglu, Félix Mathieu, Dave Guénette, André Lecours, and Christian Leuprecht for their helpful comments, as well as Melisande Charbonneau-Gravel for superb research assistance on intergovernmental agreements. We are also grateful for the financial support of the Research Support Programme of the Québec Secretariat for Canadian Relations and of the Centre de recherche interdisciplinaire sur la diversité et la démocratie (CRIDAQ).

2 The Canadian Armed Forces coordinated PPE stocks and flew them across the country to ensure that all $\mathrm{P} / \mathrm{Ts}$ had adequate supplies.

\section{References}

Adam, Marc-Antoine, Josée Bergeron and Marianne Bonnard. 2015. 'Intergovernmental Relations in Canada: Competing Visions and Diverse Dynamics', in Johanne Poirier, Cheryl Saunders and John Kincaid (eds), Intergovernmental Relations in Federal Systems: Comparative Structures and Dynamics, pp. 135-73, Don Mills: Oxford University.

Attaran, Amir and Adam R. Houston. 2020. 'Pandemic Data Sharing: How the Canadian Constitution Has Turned into a Suicide Pact', in Colleen M. Flood et al. (eds), Vulnerable: The Law, Policy and Ethics of COVID-19, pp. 91-104, Ottawa: University of Ottawa Press.

Béland, Daniel et al. 2020a. 'Social Policy Responses to COVID-19 in Canada and the United States: Explaining Policy Variations between Two Liberal Welfare State Regimes', Social Policy \& Administration, 55(2): 280-94. 
Béland, Daniel et al. 2020b. 'A Critical Juncture in Fiscal Federalism?: Canada's Response to COVID-19', Canadian Journal of Political Science, 53: 239-43.

Béland, Daniel et al. 2020c. 'COVID-19 Will Force a Change to Canada's Fiscal Arrangements', Policy Options, https://policyoptions.irpp.org/magazines/may-2020/covid-19-will-forcea-change-to-canadas-fiscal-arrangements/ (accessed on 7 May 2020).

Breton, Charles and Mohy-Dean Tabbara. 2020. 'How the Provinces Compare in Their COVID-19 Responses', Policy Options, https://policyoptions.irpp.org/magazines/april2020/how-the-provinces-compare-in-their-covid-19-responses/ (accessed on 22 April 2020).

Broschek, Jörg. 2020. 'Bicameralism and the Consequences of Political Structuring in Canada: Lost Alternatives, Future Options', in Alain G. Gagnon \& Johanne Poirier (eds), Canadian Federalism and Its Future: Actors and Institutions, pp. 53-83, Montréal/Kingston: McGill-Queen's University Press.

Carling, Amanda and Insiya Mankani. 2020. 'Systemic Inequities Increase Covid-19 Risk for Indigenous People in Canada', Human Rights Watch, https://www.hrw.org/ news/2020/06/09/systemic-inequities-increase-covid-19-risk-indigenous-people-canada (accessed on 9 June 2020).

Chouinard, Stéphanie and Martin Normand. 2020. 'Talk COVID to Me: Language Rights and Canadian Government Responses to the Pandemic', Canadian Journal of Political Science, 53(2): 259-64.

Da Silva, Michael and Maxime St-Hilaire. 2020. 'Pandemic Preparedness and Responsiveness in Canada:Exploring the Case for an Intergovernmental Agreement', Centre for Constitutional Studies Blog, https://ualawccsprod.srv.ualberta.ca/2020/06/pandemic-preparednessand-responsiveness-in-canada-exploring-the-case-for-an-intergovernmental-agreement/ (accessed on 15 June 2020).

Daly, Paul. 2020a. 'Governmental Power and COVID-19: The Limits of Judicial Review', in Colleen M. Flood et al. (eds), Vulnerable: The Law, Policy and Ethics of COVID-19, pp. 211-22, Ottawa: University of Ottawa Press.

Daly, Paul. 2020b. 'Regulating the Covid-19 Pandemic: Forms of State Power and Accountability Challenges', Centre for Constitutional Studies, https://ualawccsprod.srv. ualberta.ca/2020/05/regulating-the-covid-19-pandemic-forms-of-state-power-andaccountability-challenges/ (accessed on 7 May 2020).

Deschenes, Michel. 1992. 'Les pouvoirs d'urgence et le partage des compétences au Canada', Cahiers de droit, 33(4): 1181-1206.

Fierlbeck, Katherine and Lorian Hardcastle. 2020. 'Have the Post-SARS Reforms Prepared Us for COVID-19? Mapping the Institutional Landscape', in Colleen M. Flood et al. (eds), Vulnerable: The Law, Policy and Ethics of COVID-19, pp. 31-48, Ottawa: University of Ottawa Press.

Flynn, Alexandra. 2020. 'Municipal Power and Democratic Legitimacy in the Time of COVID-19', in Colleen M. Flood et al. (eds), Vulnerable: The Law, Policy and Ethics of COVID-19, pp. 127-38, Ottawa: University of Ottawa Press.

Framework for Mutual Aid Requests (OFMAR).n.d. http://publications.gc.ca/collections/ collection_2018/aspc-phac/HP45-13-2017-eng.pdf (accessed on 13 November 2020).

Gagnon, Alain G. and Johanne Poirier (eds). 2020. Canadian Federalism and its Future: Actors and Institutions, Montreal and Kingston: McGill-Queen's University Press.

Gaudreault-DesBiens, Jean-François and Johanne Poirier. 2017. 'From Dualism to Cooperative Federalism and Back? Evolving and Competing Conceptions of Canadian Federalism', in Peter Oliver, Patrick Macklem and Nathalie Desrosiers (eds), The Oxford Handbook of the Canadian Constitution, pp. 391-413, New York: Oxford University Press. 
Harell, Allison. 2020. 'How Canada's Pandemic Response is Shifting Political Views', Policy Options, http: policyoptions.irpp.org/magazines/april-2020/how-canadas-pandemicresponse-is-shifting-political-views/ (accessed on 8 April 2020).

Intergovernmental Affairs. 2020. 'Safe Restart Agreement', Government of Canada, https:// www.canada.ca/en/intergovernmental-affairs/services/safe-restart-agreement.html (accessed on 16 September 2020).

Klein, Alana. 2017. 'Jurisdiction in Canadian Health Law', in Joanna Erdman,Vanessa Gruben and Erin Nelson (eds), Canadian Health Law and Policy, 5th ed, pp. 29-50, Toronto: LexisNexis.

Lee, Marc and Armand Hamidian. 2020. 'Comparing Provincial Economic Responses to COVID-19', Policy Note, https://www.policynote.ca/provincial-responses-covid/ (accessed on 23 April 2020).

Leuprecht, Christian. 2020. 'COVID's Collateral Contagion: Why Faking Parliament Is No Way to Govern in a Crisis', MacDonald Laurier Institute Commentary, https:// macdonaldlaurier.ca/files/pdf/MLICommentary_June2020_Leuprecht_FWeb.pdf (accessed on 15 June 2020).

MacDonnell, Vanessa. 2020. 'Ensuring Executive and Legislative Accountability in a Pandemic', in Colleen M. Flood et al. (eds), Vulnerable: The Law, Policy and Ethics of COVID-19, pp. 141-62, Ottawa: University of Ottawa Press.

Mathieu, Félix and Dave Guénette. 2020 'Quebec, Canada and the Covid-19 Crisis: Making Federalism Work Again?', UACES Territorial Politics, https://uacesterrpol.wordpress. com/2020/06/16/quebec-canada-and-the-covid-19-crisis-making-federalism-workagain/ (accessed on 16 June 2020).

McNeill, R. and J.Topping. 2018. 'Federal, Provincial and Territorial Public Health Response Plan for Biological Events', Canadian Communicable Disease Report, 44(1): 1-5.

Migone, Andrea. 2020. 'Trust, but Customize: Federalism's Impact on the Canadian COVID-19 response', Policy \& Society, 39(3): 382-402.

National Assembly. 2020. Débats de l'Assemblée nationale, 45(120), 12 June P 8270.

National Defence. 2020. 'Operation LASER', Government of Canada, https://www. canada.ca/en/department-national-defence/services/operations/military-operations/ current-operations/laser.html (accessed on 10 July 2020).

Noël, Alain. 2020. 'COVID-19 et tensions intergouvernementales?', Policy Options, https:// policyoptions.irpp.org/magazines/may-2020/covid-19-et-tensions-intergouvernementaleschronique-dalain-noel/ (accessed on 4 May 2020).

Pan-Canadian Public Health Network. 2009. Memorandum of Understanding on the Provision of Mutual Aid in Relation to Health Resources during an Emergency Affecting the Health of the Public, http://www.phn-rsp.ca/pubs/mou-ma-pe-am/index-eng.php (accessed on 1 October 2020).

Pan-Canadian Public Health Network. 2014. Multilateral Information Sharing Agreement, http://www.phn-rsp.ca/pubs/mlisa-emer-eng.php (accessed 1 October 2020).

Pan-Canadian Public Health Network. 2018a. Federal/Provincial/Territorial Response Plan for Biological Events. Catalogue No. HP45-20/2018E-PDFR. Ottawa: Minister of Health.

Pan-Canadian Public Health Network. 2018b. Canadian Pandemic Influenza Preparedness: Planning Guidance for the Health Sector. Catalogue No. HP40-144/2018E-PDF. Ottawa: Minister of Health.

Poirier, Johanne. 2004. 'Intergovernmental Agreements in Canada: At the Crossroads between Law and Politics', in Peter Meekison, Hamish Telford, and Harvey Lazar (eds), Reconsidering the Institutions of Canadian Federalism, pp. 425-62. Kingston: Institute of Intergovernmental Relations. 
Poirier, Johanne. 2020. 'The 2018 Pan-Canadian Securities Regulation Reference: Dualist Federalism to the Rescue of Cooperative Federalism', Supreme Court Law Review, 94 (2): 85-123.

Poirier, Johanne and Sajeda Hedaraly. 2020. 'Truth and Reconciliation Calls to Action across Intergovernmental Landscapes: Who Can and Should Do What?', Review of Constitutional Studies, 24(2): 171-206.

Public Health Agency of Canada. 2020a. Data on COVID-19 in Canada, https://open.canada. ca/data/en/dataset/261c32ab-4cfd-4f81-9dea-7b64065690dc (accessed on 31 Oct 2021).

Public Health Agency of Canada. 2020b. Federal/Provincial/Territorial Public Health Response Plan for Ongoing Management of COVID-19. Ottawa: Minister of Health.

Sahota, Ruby. 2020. Parliamentary Duties and the COVID-19 Pandemic: Report of the Standing Committee on Procedure and House Affairs. Ottawa: House of Commons.

Schertzer, Robert and Mireille Paquet. 2020a. 'How Well is Canada's Intergovernmental System Handling the Crisis?', Policy Options, https://policyoptions.irpp.org/magazines/ april-2020/how-well-is-canadas-intergovernmental-system-handling-the-crisis/ (accessed on 8 April 2020).

Schertzer, Robert and Mireille Paquet. 2020b. 'COVID-19 as a Complex Intergovernmental Problem', Canadian Journal of Political Science, 53(2): 343-7.

Steytler, Nico. 2017. 'The Currency of Concurrent Powers', in Nico Steytler (ed.), Concurrency Powers in Federal Systems: Meaning, Making, Managing, pp. 1-11. Leiden/ Boston: Brill Nijhoff. 